\title{
INFLUENCE OF BIOGAS DIGESTERS ON FAECAL INDICATOR ORGANISMS IN DIGESTATE AND AROUND HOMESTEADS IN ETHIOPIA
}

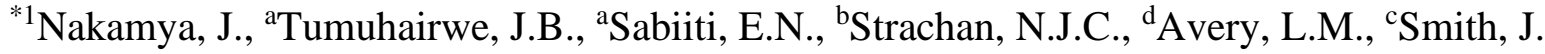 \\ ${ }^{a}$ Department of agricultural Production, School of Agricultural Sciences, College of Agricultural \\ and Environmental Sciences, Makerere University \\ ${ }^{b}$ The School of Natural and Computing Sciences, Aberdeen University \\ ${ }^{\mathrm{c}}$ The Institute of Biological and Environmental Sciences, Aberdeen University \\ ${ }^{\mathrm{d}}$ Environmental and Biochemical Sciences/ Centre for Human and Animal Pathogens in the \\ Environment, James Hutton Institute, Aberdeen. \\ *Corresponding author: janienaka@gmail.com
}

\section{Abstract:}

It is important, prior to application of organic wastes to land, that pathogen loads are reduced sufficiently to minimize dissemination to the wider environment. Anaerobic digestion for biogas production is a low-cost method to reduce pathogens in agricultural wastes that provides the added benefits of energy generation. There have been claims of pathogen reduction following installation of biogas digesters in homesteads in Sub-Saharan Africa. Homestead pathogen levels following installation of the different designs of biogas digester were monitored using faecal indicator organisms within small rural farms in Ethiopia. However, different designs of digesters have registered varying levels of success. Of the three digester designs considered, fixed dome, floating drum and flexible balloon, the fixed dome design achieved the highest reductions in indicator organisms (coliforms, Escherichia coli and Enterococci) from feedstock to digestate; this is likely to be due its longer hydraulic retention time. Households with biogas digesters installed had significantly $(\mathrm{p}<0.05$ ) lower levels of coliforms, E. coli and Enterococci detected in the environment inside and outside the house area. However, in the same households, there was a significant $(\mathrm{p}<0.05)$ increase in indicator organisms on the surface and handles of doors, indicating the potential for spread of pathogens on contaminated hands to door handles from handling the animal waste feedstock. This therefore, suggests the need for proper hand washing regimes after handling of feedstocks for biogas digesters.

\section{Introduction}

In recent years, there has been a drastic decline in the availability of biomass fuels across many parts of Africa arising from increasing deforestation, partly due to collection of wood for fuel (Eleri \& Eleri, 2009). In Ethiopia, where forest cover is already less than 5\% of the total country's land area, the remaining area of forest decreases by 5\% each year (FAO, 2015). With an effort to preserve tree cover, different energy sources are being investigated, including liquefied petroleum gas, electricity, solar energy and biogas. The main focus has been on electricity production, which 
is favored in Ethiopia because of the high value attached to it by local communities. However, there remains poor access to electricity in rural areas where capital investment costs are high (Luijten \& Kerkhof, 2011). Due to the cost of of installation and production, very few people outside urban areas (2\%) have access to it (IEA -International Energy Agency, 2011). The rate of use of petroleum hydrocarbons in homesteads in Ethiopia remains very low in rural areas, where only $1.3 \%$ of households, accounting for 93 million people, rely on petroleum hydrocarbon sourced energy (Eleri \& Eleri, 2009). Consequently, wood and charcoal are still widely used, and in some cases, this will contribute to increased deforestation, biomass loss and associated land degradation (Hoffmann, 2016).

In recent years, there has also been an increased emphasis on solar and biogas technologies (Gu et al., 2016). The potential for adoption of biogas in rural Africa is high with $36 \%$ of the population in the rural areas (over 6 billion people) owning livestock (Staal et al., 2009). In Africa, Ethiopia has the greatest number of livestock; 60 million cattle, 60 million sheep and goats, 52 million chickens \& 4.5 million camels (Tegegne \& Gatachew, 2020). Therefore, there is great potential for development of biogas technology using animal manures (Gebreegziabher et al., 2014). Of agricultural households, $77 \%$ are cattle owners, although this varies greatly from region to region (Lindfors, 2010). In China, it has been suggested that biogas from cattle manure could be a major substitute for wood fuel and electricity to meet the energy needs of the rural population (Gu et al., 2016). With the high numbers of livestock, there may be similar potential for biogas production in Ethiopia. Most importantly, the production of biogas is relatively simple and can operate under both tropical and temperate conditions (Itodo et al., 2007).

Biogas is produced by a simple process, that uses anaerobic digestion of animal and plant wastes to produce a gas containing 60-70\% methane that can be used for cooking and lighting (Itodo et al., 2007). Anaerobic digestion also offers the potential of a low-cost method to reduce pathogens in agriculture wastes (Avery et al., 2014), and so is a possible method to manage organic waste with the added benefits of energy generation. Organic wastes from animal, human and plant sources are suitable feedstocks for biogas production. However, these wastes also contain numerous protozoa, bacteria, fungi and viruses, a number of which can cause diseases to humans (Nelson \& Murray, 2008) and animals (Gannon et al., 2012). The major species of concern are enteric bacteria, such as Salmonella sp, Listeria spp, Escherichia coli, Bacillus spp, 
Campylobacter spp, Mycobacteria spp, Clostridia spp, Brucella spp and Yersinia spp (Sobsey, 2006). These pathogens may enter into the food chain via contaminated crops and meat products or may infect humans and livestock populations via direct contact with manure.

Manures are widely handled in Ethiopia where they are formed into patties and used as cooking fuel, a custom which inevitably presents a major route of exposure to humans (Johannessen et al., 2004). The process of anaerobic digestion may reduce pathogen loads in the digestate relative to the feedstock (Avery et al., 2014). This could mitigate some risks of high concentrations of pathogens being disseminated to the wider environment and into the food chain. Adoption of biogas as a cooking fuel may reduce the use of dung patties, so reducing direct contact exposure. However, alternative manure handling practices are likely to arise as manures must be moved from source into the biogas digester. As observed by Tumwesige et al. (2013) during previous studies in Uganda, this may also result in households changing their livestock husbandry practices; for example keeping livestock corralled closer to the house for easier manure collection for the digester. Spread of manure close to the house may also result from spillage while conveying and loading it into the digester. It is not clear what effect this will have on the overall burden of pathogens in and around the home, and the overall impact on exposure to pathogens.

Pathogen die-off during anaerobic digestion arises primarily due to raised temperatures, increased competition for microbial food sources and conditions that are non-ideal for particular species (Rajendran et al., 2012). However, it is not known whether small scale household anaerobic digestion reduces pathogen levels (widely evaluated using faecal indicator organisms - FIOs) to acceptable standards. In the US, these standards correspond to 100,000, 10,000 and 100 coliform forming units (CFU) per $\mathrm{ml}$ for Enterococci, coliforms and E.coli respectively (United States Enviromental Protection Agency, 2013).

Biogas digester technology is advancing in Ethiopia, and several designs have been developed and are available on the market. These include flexible balloon, floating drum and fixed dome digesters (Semple et al., 2014). However, there is little or no provision of guidelines for handling of animal wastes, and the digesters themselves are likely to have different levels of efficacy in digesting and sanitizing wastes. 
This study uses standard FIOs to determine the capacity of a range of small-scale biogas digester designs to reduce pathogen loads in feedstock as well as in and around households in rural Ethiopia. The study aimed to determine whether introduction of different designs of biogas digesters to small rural farms in Ethiopia is likely to increase or reduce overall exposure of farmers and householders to zoonotic pathogens.

\section{Materials and methods}

\section{Description of the study area}

The study was conducted in Kumbursa village in the Ada'a district of Ethiopia. Kumbursa is located at distance of approximately $55.5 \mathrm{~km}$ East of Addis Ababa between $8^{\circ} 411^{\prime} 1(0.13 \mathrm{~km})^{\prime \prime}$

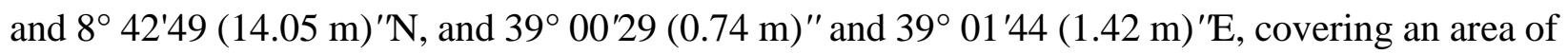
$\sim 640$ ha (Figure 1) The village is at an altitude of 1888-1992 $\mathrm{m}$ above sea level and is characterized as "Woina dega" traditional agroclimatic zone Precipitation in Kumbursa originates from the South-West equatorial air stream. The rainfall distribution pattern is uni-modal, with a peak between June and September (74 \% of the mean annual precipitation), and a total annual average of $800 \mathrm{~mm}$ (Minase et al., 2016) . The annual mean temperature of the area ranges from 16.3 $19.7^{\circ} \mathrm{C}$, with a ten-year mean of $18.1^{\circ} \mathrm{C}$ and the hottest months in March, April and May (Minase et al., 2016).

\section{Study design}

Twelve households in Kumbursa were purposively selected on the basis that they have the same number of livestock (at least 10 cows), similar agricultural activities and similar homestead structures. The main criterion for selection was households that can generate the critical mass of feedstock of at least $80 \mathrm{~kg}$ per day required to sustain biogas generation (Semple et al., 2014). The households were randomly divided into four equal groups. Each group was fitted with digesters of one of three designs; (i) fixed dome, (ii) flexible balloon or (iii) floating drum, with the other group without biogas digesters installed serving as control households. A randomized complete block design was used, with households in the location using the same water source but with one of each different biogas digester designs installed within the block. This was done to minimize any bias due to water source. As is normal practice, fixed dome digesters with a volume of $16 \mathrm{~m}^{3}$ were installed underground to maintain stable temperatures, flexible balloon digesters with a volume of 
$12 \mathrm{~m}^{3}$ were installed in a ditch and under the shade, and floating drum digesters with a volume of $8 \mathrm{~m}^{3}$ were installed above ground.

\section{Sampling for Faecal Indicator Organisms}

\section{Sampling of feedstock and digestate}

Digesters were fed daily throughout the experimental period with manure mixed with $100-120$ $\mathrm{dm}^{3}$ of water in a ratio of 1:1. Assuming the typical feedstock to gas ratio of 5:1 (Smith et al., 2013), this gives hydraulic retention times of 60,45 and 30 days for the fixed dome, flexible balloon and floating drum digesters, respectively; the ratio of hydraulic retention times is 2.0 (fixed dome) : 1.5 (flexible balloon) : 1.0 (floating drum). Once biogas generation had begun, $10 \mathrm{ml}$ samples of feedstock (at the time of feeding which was carried out daily) and digestate (at the HRT) were obtained from each of the digesters concurrently with the household environmental sampling, within the five months period of the experiment. Samples were collected in sterile vials and kept cool as described above until analysis on return to the laboratory.

\section{Sampling around households}

In this study total coliforms, E. coli and Enterococci were used as FIOs for pathogen load and sanitization. These organisms are used internationally in environmental standards and, therefore, this allows findings to be compared widely with other work. After installation of the biogas digesters, FIO loads around the inside and outside floor environments of the household were tested on two occasions. This was done using boot swabs ( Bowden and Knights, UK) which were worn on top of the boot to obtain environmental samples. On each occasion, fifty paces were taken outside the house in the yard area with one boot swab and 20 inside the house with a second boot swab. This approach has been previously demonstrated to provide a suitable method for swabbing a complex environment where intensive sampling regimes are not logistically possible (Public Health England, 2013). Boot swabs were removed and placed in individual filter bags and kept cool in a cool box with ice for 2 hours during transit to the laboratory. On each occasion, a further sample was obtained from the door handles using a wet swab which was then placed in an isotonic transport diluent (Amies clear, plastic shaft) (Fisher, UK). Samples were obtained from all twelve households (with and without biogas digesters) in the study over a 3-month period during the hottest period of the year (March - July 2015). 


\section{Analysis of Faecal Indicator Organisms}

Enumeration of FIOs from boot swabs taken outside and inside the house was performed using a Colilert and Enterolert most probable number (MPN) methods (Idexx, UK) according to manufacturer's instructions. To generate the inoculum, the swabs were washed in $100 \mathrm{ml}$ of sterile water in a filter bag, divided into $50 \mathrm{ml}$ aliquots, diluted 1:2 (volume/volume (V/V)) and shaken (25 revolutions per minute (rpm); 30 seconds). Further dilutions were carried out as required before inoculating quanti-trays. For the door knob samples, $5 \mathrm{ml}$ of transport diluent was added to $95 \mathrm{ml}$ of sterile water, shaken as above and then further diluted before inoculating quanti-trays.

Samples from the feedstock and digestate were analysed by first performing a ten-fold dilution (V/V); $10 \mathrm{ml}$ of the sample was placed in the filter bag to which $90 \mathrm{ml}$ sterile water was added. Further ten-fold dilutions were prepared as necessary to obtain readable counts Coliforms, E. coli and Enterococci were enumerated by the methods described above.

\section{Data analysis}

All microbial counts were normalized by $\log _{10}$ - transformation prior to analysis of variance (ANOVA) by biogas digester type (Gen stat $12^{\text {th }}$ edition). One way ANOVA was also performed to the effect of treatments (households at which biogas digesters were installed; control houses without digesters) for all FIO combined. The means were compared using the least significant differences (LSD) at $\mathrm{p}<0.05$. Finally, the mean number of each FIO detected in digestate was compared with acceptable levels of waste disposal, which were assumed to be 100,000, 10,000 and $100 \mathrm{CFU} / \mathrm{ml}(5,4$ and $2 \log 10 \mathrm{CFU} / \mathrm{ml})$ for Enterococci, coliforms and E.coli respectively for safe disposal of digestate (US EPA, 2013).

\section{Results}

\section{Sanitization of manure: Changes in Faecal Indicator Organisms counts during digestion}

In the feedstock, the FIO load was above the US EPA (2013) acceptable standards for waste disposal for all organisms except Enterococci. Therefore, the feedstock would require sanitization before safe disposal. All the biogas digester designs significantly $(\mathrm{p}<0.05)$ reduced the population of total coliforms and E. coli compared to the feedstock. However, while the Enterococci 
population was reduced to 2.5 (standard error ( \pm ) 0.2) $\log _{10}$ and $3.5( \pm 0.2) \log _{10} \mathrm{CFU} / \mathrm{ml}$ in the 189 fixed dome and flexible balloon digesters respectively, it increased to above the acceptable level of $5.0 \log _{10} \mathrm{CFU} / \mathrm{ml}$ to $5.5( \pm 0.2) \log _{10} \mathrm{CFU} / \mathrm{ml}$ in the floating drum biogas digester design (Fig.

191 1). The reductions between the fixed dome and flexible balloon were not significantly different, 192 suggesting no additional benefit in sanitation was achieved by increasing the hydraulic retention 193 time to above the 45 days in the flexible balloon digester to 60 days in the fixed dome digester.

194 The fixed dome and flexible balloon digesters reduced Enterococci and coliforms to below US 195 EPA standards of 5 and $4 \log _{10} \mathrm{CFU} / \mathrm{ml}$ respectively, but the reduction in E.coli was insufficient 196 for safe disposal. The floating drum design, with its shorter hydraulic retention time, did not attain 197 acceptable standards for disposal for any of the FIOs (Fig. 1).

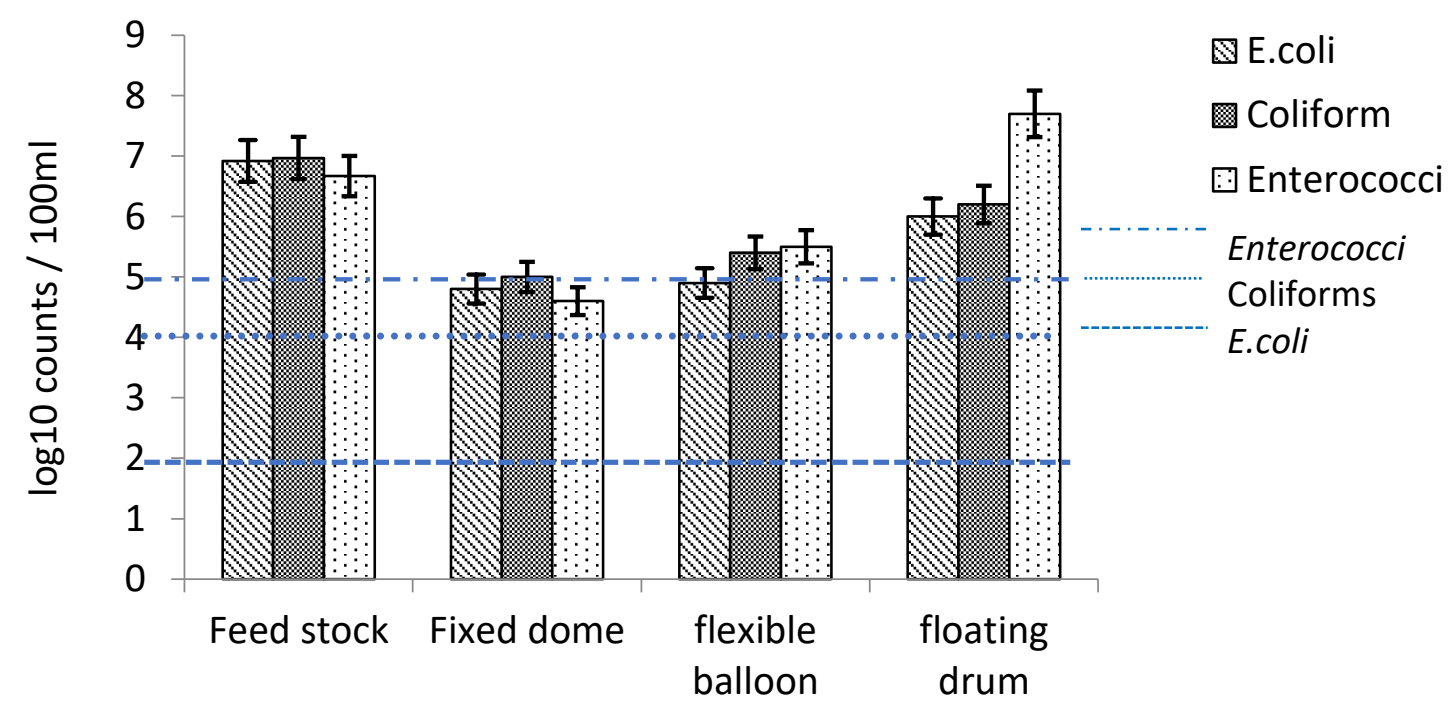

Households

Figure 1: Concentrations of coliforms, E. coli and Enterococci in feedstock and digestate from different biogas digester designs installed in Households of Kumbursa, Ethiopia 
Installation of biogas digesters in the household significantly $(\mathrm{p}<0.05)$ increased counts of coliforms and E. coli on door swabs (Fig. 2). Coliforms significantly increased by $1.7( \pm 0.2) \log _{10}$ $\mathrm{CFU} / \mathrm{ml}$ for floating drum digesters by $2.8( \pm 0.2) \log _{10} \mathrm{CFU} / \mathrm{ml}$ for flexible balloon digesters and by $2.2( \pm 0.2) \log _{10} \mathrm{CFU} / \mathrm{ml}$ for fixed dome. There was only a significant increase in E. coli (2.8 $( \pm 0.4) \log _{10} \mathrm{CFU} / \mathrm{ml}$ ) (on door knobs where households had floating drum digesters. at 2.8 $( \pm 0.4) \log _{10} \mathrm{CFU} / \mathrm{ml}$; this increased $E$. coli to above safe levels $\left(2 \log _{10} \mathrm{CFU} / \mathrm{ml}\right)$. The trends did not align with the performance or hydraulic retention times of the digesters, suggesting that contamination occurs on feeding the digester, rather than on handling the digestate.

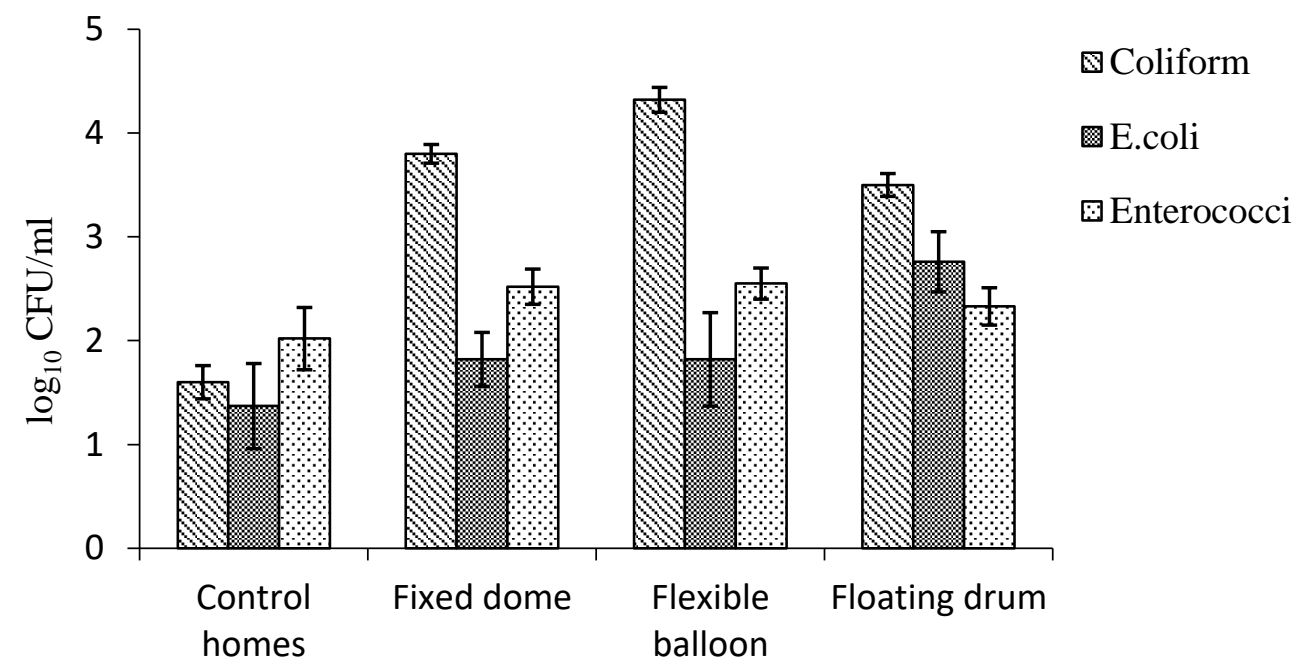

Households

Figure 2: Concentration of coliforms, E.coli and Enterococci from door swabs of with and without biogas digester from households in Kumbursa, Ethiopia

Faecal Indicator Organisms counts inside and outside households with and without biogas digesters

The counts inside the households of all FIO considered were significantly $(\mathrm{p}<0.05)$ reduced in homes where biogas digesters had been installed (Fig.3). Coliforms were reduced by all types of digester from $5.6( \pm 0.1) \log _{10}$ MPN / swab in households without biogas digesters to $3.7( \pm 0.05)$; $3.4\left( \pm\right.$ ?) and $3.0( \pm 0.05) \log _{10}$ MPN / swab in households with floating drum digesters; flexible balloon digesters and fixed dome digesters respectively. E. coli and Enterococci followed a similar pattern, E. coli was reduced from $4.5( \pm 0.4) \log _{10}$ MPN / swab in the control to $2.5( \pm 0.2) ; 1.4$ 
$224( \pm$ ?) and1.8 ( \pm 0.2$) \log _{10}$ MPN / swab in households with floating drum digesters; flexible balloon 225 digesters and fixed dome digesters respectively. Enterococci were reduced from $4.5( \pm 0.2) \log _{10}$ 226 MPN / swab in the control to $3.5( \pm 0.4) ; 3.2( \pm ?)$ and $3.6( \pm ?) \log _{10}$ MPN / swab in households with 227 floating drum digesters; flexible balloon digesters and fixed dome digesters respectively. The 228 broad correspondence between the reduction in FIO inside households and digester performance 229 of the different designs of digesters suggests that the lower counts inside the household is due to 230 the reduction in organisms in the digestate.

231 Installation of biogas digesters also significantly $(\mathrm{p}<0.05)$ reduced the population of FIOs outside 232 the house in the same order: fixed dome>flexible balloon> floating drum>(Fig.4). E. coli counts 233 were reduced the most from $3.3( \pm 0.4) \log 10 \mathrm{MPN} / \mathrm{swab}$ in households without biogas digesters 234 to between $2.0( \pm 0.4) \mathrm{MPN} / \mathrm{swab}$ for the fixed dome and $2.4( \pm 0.4) \log 10 \mathrm{MPN} / \mathrm{swab}$ for the 235 floating drum digester. Enterococci were reduced from $4.4( \pm 0.2) \log 10 \mathrm{MPN} / \mathrm{swab}$ in the control 236 households to $3.0( \pm 0.4)$ (fixed dome) to $3.6( \pm 0.4) \log 10 \mathrm{MPN} / \mathrm{swab}$ (floating drum). Coliforms 237 were reduced from $4.2( \pm 0.4) \mathrm{MPN} /$ swab in the control to between $3.2( \pm 0.1) \mathrm{MPN} / \mathrm{swab}$ in the 238 fixed dome to $3.6( \pm 0.1) \mathrm{MPN} / \mathrm{swab}$ in the floating drum.

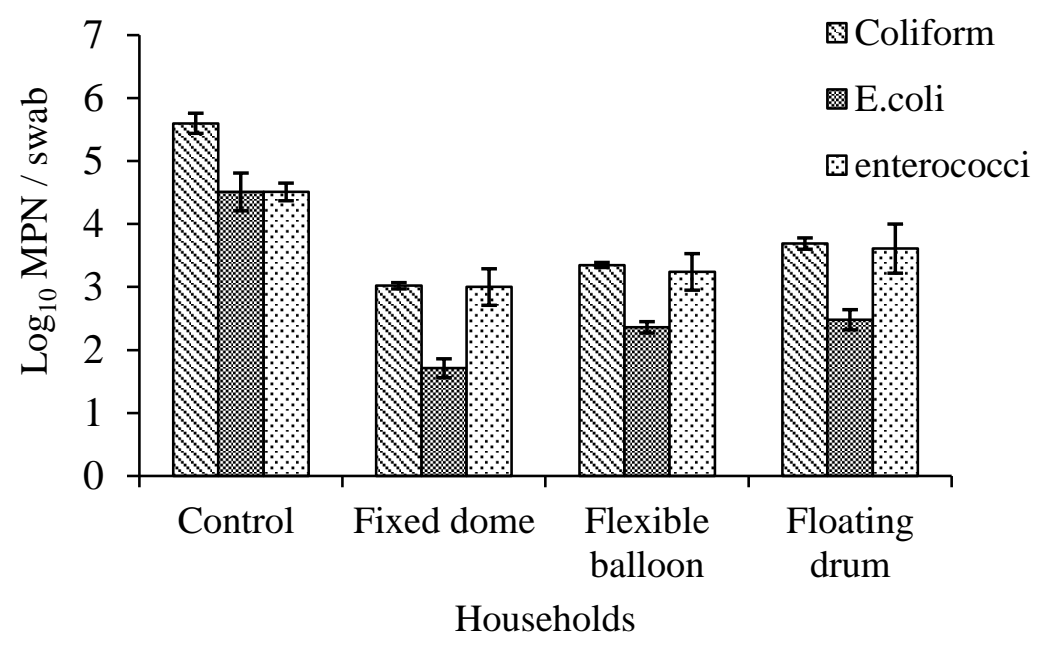

241 Figure 3: Population of coliforms, E.coli and Enterococci inside the households with and without biogas digester 


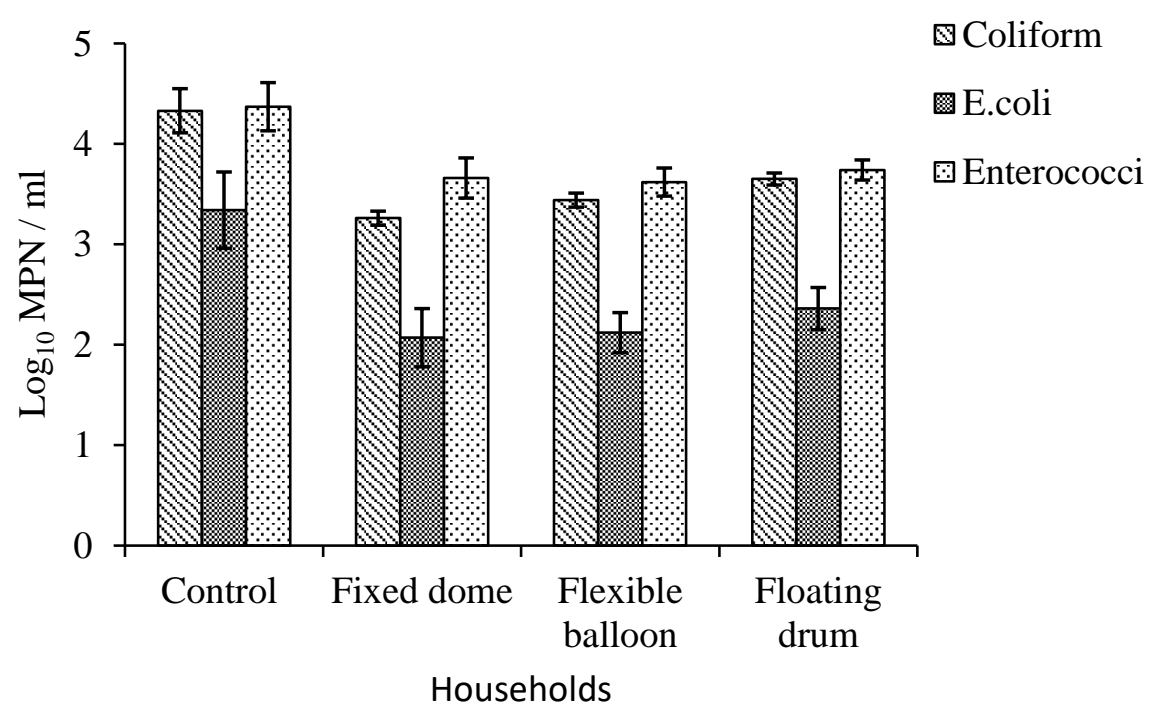

243 Figure 4 Population of coliforms, E.coli and Enterococci from outside of houses of the household of Kumbursa, Ethiopia

245 Discussion

246 Reductions in faecal indicator organisms counts from feedstock to digestate

247 All three biogas digester designs significantly reduced the population of total coliforms and E. coli

248 during digestion of feedstock. As mesophiles, coliforms and E. coli are sensitive to elevated

249 temperatures of $45-60{ }^{\circ} \mathrm{C}$ and $\mathrm{pH}$ values below 6 and above 9. In a review of the literature, Avery

250 et al. (2014) reported typical removals of $2 \log _{10} \mathrm{CFU} / \mathrm{ml}$ during mesophilic digestion. Production

251 of organic acids during methanogenesis reduces the $\mathrm{pH}$ of the digestate (Chaudhry \& Mukherjee,

252 2016). The E. coli and total coliform counts were similar in feedstock and digestate of the different

253 digesters indicating that $E$. coli being a subclass of coliforms, it dominated the coliform

254 populations.

256 The digesters used in this study were selected because they are the most commonly adopted small 257 scale biogas digester designs in Africa, and are locally available in Ethiopia. These designs have 258 different hydraulic retention times, and the results obtained reflect this. The hydraulic retention 259 time of feedstock or digestate in the biogas digester is well known to influence FIO die-off (Horan 260 et al., 2004). The retention times of the floating drum, flexible balloon and fixed dome used in the 261 study were 30, 45 and 60 days respectively, which broadly corresponded to increasing FIO 
reductions. The biogas digesters' failure in reduction of E. coli to below acceptable standards indicates that the HRT of 60 days and below is not sufficient enough to reduce E. coli. (ManyiLoh et al., 2016) suggested that even combination of two or more methods of treatment might be the most effective way to control spread of pathogens from animal manures, for example biogas digesters followed by composting.

Enterococci have been shown to be more resistant that E. coli during anaerobic digestion, particularly at higher temperatures (Watcharasukarn et al., 2009). The capability of Enterococci to withstand harsh conditions for some period of time contributed to its populations remaining significantly higher than coliforms and E. coli in all types of digester (Fig.4). In the floating drum digester, where the hydraulic retention time was only 30 days, not only did Enterococci not decrease, but they actually increased, indicating that the conditions were suitable for growth. Enterococci are indeed resistant to mesophilic temperatures $\left(35-45^{\circ} \mathrm{C}\right)$ and have been shown to be more resistant than faecal coliforms to biosolids treatment processes, including mesophilic anaerobic digestion and composting (Bonjoch \& Blanch, 2009; Viau \& Peccia, 2009) (Martínez et al., 2003; Watharasukarn et al., 2009).

\section{Reductions in faecal indicator organisms counts in homesteads environments with and} without biogas digesters

The presence of fixed dome, floating drum and flexible balloon designs of biogas digester significantly reduced the populations of FIOs both inside and outside in the house. By contrast, the door handles of households with biogas digesters installed had significantly higher levels of FIOs than those without. This is likely to be attributable to contamination of hands from handling manure during collection from the compound and mixing while feeding the biogas digester. It was observed that during the collection and mixing of feedstock manure, most household members used their hands without protective gloves, so there is a clear pathway of contamination from manure to hands to door handles. The variation of FIO load across different biogas digester designs is explained by the floating and fixed dome digesters having larger volumes compared to the floating drum design. This required increased feeding frequency increasing the time of handling manure and hence resulted in greater transfer of pathogens to hands, which were then transferred to door handles. Our results indicate that while the ground was less contaminated, likely as a result of gathering manure for digestion, the handling of manure for this purpose could potentially 
increase human exposure to pathogens. Therefore, there is an important hygiene message which must be clearly emphasized when introducing digesters into rural communities. To reduce likelihood of spreading pathogens, it is critical for householders to wash their hands thoroughly after handling feedstock manures. Since biogas digesters do not completely eliminate the FIOs and pathogens,this also applies to handling the digestate.

It was noted that having a biogas digester at the homesteads significantly reduced coliform, $E$. coli and Enterococci abundance on the indoor boot swabs (Fig. 3). This is likely to be a direct effect of the reduction in FIOs on the ground around the outside of the homes, which may have been due to gathering of dung from these areas to feed digesters, or changes in animal husbandry practices to facilitate easier collection of manures. Dung is a vehicle for transmission of pathogenic to the wider environment (Nelson \& Murray, 2008). Therefore, when waste accumulates in the compound or outside the household, this provides a reservoir for transmission into the household. Households with biogas digesters collect and process the dung for biogas, so avoiding manure accumulation and maintaining a lower load of manure-derived microorganisms around the homestead. This is supported by the fact that of the three FIOs, it was the E. coli load that was most reduced both during digestion, and in the indoor and outdoor floor samples. One confounding factor in interpreting FIO loadings in the household environment in Ethiopia is that farming householders' use dung to build and cement their houses, which may contribute to the observed FIOs when dung used for building is still fresh. In contrast to this study Harroff et al., (2011) reported that households with biogas digesters in Tiribogo, Central Uganda, had higher levels of FIO inside the houses than those without biogas digesters. This could be attributed to difference in the behavior of Ugandan farmers compared to farmers in Ethiopia. In Uganda most farmers keep livestock, such as goats inside their houses, which is not the case in Ethiopia.

It is also likely that the reduction of pathogens in the biogas digester sanitization played a direct role in reducing the pathogen inputs to the wider environment surrounding digester homesteads (Tate et al., 2006). Of the three designs, the reduction in pathogens inside and outside the household was least in the floating drum digester, which has the lowest hydraulic retention time. This suggests that handling of the digestate could also have contributed to pathogen levels around the home. Counts of E. coli on door handles increased the most in homes fitted with a floating 
324 drum digester; this being the design of digester that least reduces the levels of E. coli in the 325 digestate. However, the ratio of coliforms to E. coli is higher than that in the feedstock and 326 digestate, indicating that there is a further source of coliforms or the coliforms survive better than 327 E. coli on the surfaces tested.

328

329

330

331

332

333

334

335

336

337

338

339

340

341

342

343

344

345

346

347

348

349

350

351

352

Conclusions

i. $\quad$ Fixed dome and flexible balloon digesters reduced FIOs to a similar degree and were both more effective than the floating drum digesters. This is likely to be due to the longer hydraulic retention time in these digesters (> 45 days).

ii. The biogas digester designs in this study did not reduce all pathogens to below acceptable levels (US EPA, 2013). Therefore sanitisation of digestate could be improved in rural Ethiopia by application of a supplemental treatment such as composting.

iii. While digestion of animal manure is likely to reduce the pathogen burden in digestate for application to land and can reduce environmental contamination inside and outside the household, associated changes in practices may lead to increased exposure to microorganisms derived from dung through increased handling of manure; this was demonstrated by elevated FIO counts on door handles of homes with digesters.

iv. Improved education in hygiene of handling both manures and digestate is needed to maximize the potential benefits of pathogen reduction through anaerobic digestion in rural Africa

\section{Acknowledgement}

This work was funded by AUC/ EUC (Afri-flame network); the authors would like to thank the laboratory and field assistants who participated in this study.

\section{References}

Avery, L. M., Anchang, K. Y., Tumwesige, V., Strachan, N., \& Goude, P. J. (2014). Potential for 
pathogen reduction in anaerobic digestion and biogas generation in Sub-Saharan Africa. Biomass and Bioenergy, 70(0), 112-124. https://doi.org/10.1016/j.biombioe.2014.01.053

Bonjoch, X., \& Blanch, A. R. (2009). Resistance of faecal coliforms and enterococci populations in sludge and biosolids to different hygienisation treatments. Microbial Ecology, 57(3), 478-483. https://doi.org/10.1007/s00248-008-9430-7

Chaudhry, N., \& Mukherjee, T. K. (2016). Differential effects of temperature and $p H$ on the antibiotic resistance of pathogenic and non-pathogenic strains of Escherichia coli. 8(9), 710. https://doi.org/10.22159/ijpps.2016v8i9.12664

Eleri, A. I., \& Eleri, E. O. (2009). Rethinking Biomass Energy in Sub-Sahara Africa 200 9. 3. file:///C:/Documents and Settings/16600495/My Documents/Downloads/091124_ArfikasPerspektive_Bioenergiestudie_Final.pdf

FAO. (2015). Global Forest Resources Assessment 2015: How Are the World's Forests Changing?

Gannon, V., Grace, D., \& Atwill, E. R. (2012). Zoonotic waterborne pathogens in livestock and thier excreta - interventions (R. B. and V. G. Al Dufour, Jamie Bartram (ed.)). IWA Publishing.

Gebreegziabher, Z., Naik, L., Melamu, R., \& Balana, B. B. (2014). Prospects and challenges for urban application of biogas installations in Sub-Saharan Africa. Biomass and Bioenergy, 70, 130-140. https://doi.org/10.1016/j.biombioe.2014.02.036

Gu, L., Zhang, Y. X., Wang, J. Z., Chen, G., \& Battye, H. (2016). Where is the future of China's biogas? Review, forecast, and policy implications. Petroleum Science, 13(3), 604-624. https://doi.org/10.1007/s12182-016-0105-6

Harroff, V. Tumwesige, A. Apsley, L. A. J. S. (2011). Reduction of pathogrnic bacteria in organic waste through production of biogas.

Hoffmann, H. (2016). Wood Energy in Sub-Saharan Africa: How to Make a Shadow Business Sustainable Wood Energy in Sub-Saharan Africa: How to Make a Shadow Business. August.

Horan, N. J., Fletcher, L., Betmal, S. M., Wilks, S. a, \& Keevil, C. W. (2004). Die-off of enteric bacterial pathogens during mesophilic anaerobic digestion. Water Research, 38(5), 11131120. https://doi.org/10.1016/j.watres.2003.12.004

IEA -International Energy Agency. (2011). World Energy Outlook.

Itodo, I., Agyo, G., \& Yusuf, P. (2007). Performance evaluation of a biogas stove for cooking in Nigeria. Journal of Energy in Southern Africa, 18(3), 14-18. http://www.sswm.info/sites/default/files/reference_attachments/ITODO 2007 Performance evaluation of a biogas stove for cooking in Nigeria.pdf 
Johannessen, G. S., Froseth, R. B., Solemdal, L., Jarp, J., Wasteson, Y., \& M. Rorvik, L. (2004). Influence of bovine manure as fertilizer on the bacteriological quality of organic Iceberg lettuce. Journal of Applied Microbiology, 96(4), 787-794. https://doi.org/10.1111/j.13652672.2004.02208.x

Lindfors, H. (2010). Household biogas digester in rural energy production: Case comparison in Cambodia, Ethiopia and Lao People "s Democratic Republic. March.

Luijten, C. C. M., \& Kerkhof, E. (2011). Jatropha oil and biogas in a dual fuel CI engine for rural electrification. Energy Conversion and Management, 52(2), 1426-1438. https://doi.org/10.1016/j.enconman.2010.10.005

Manyi-Loh, C. E., Mamphweli, S. N., Meyer, E. L., Makaka, G., Simon, M., \& Okoh, A. I. (2016). An overview of the control of bacterial pathogens in cattle manure. International Journal of Environmental Research and Public Health, 13(9). https://doi.org/10.3390/ijerph13090843

Martínez, S., López, M., \& Bernardo, A. (2003). Thermal inactivation of Enterococcus faecium: Effect of growth temperature and physiological state of microbial cells. Letters in Applied Microbiology, 37(6), 475-481. https://doi.org/10.1046/j.1472-765X.2003.01431.x

Minase.A.N, Masafu.M.M, .E.A, G., \& Wolde . T.A. (2016). Impact of tillage type and soil texture to soil organic carbon storage: The case of Ethiopian smallholder farms. African Journal of Agricultural Research, 11(13), 1126-1133. https://doi.org/10.5897/ajar2014.9233

Nelson, K. L., \& Murray, A. (2008). Sanitation for unserved populations: technologies, implementation challenges, and opportunities. Annual Review of Environment and Resources, 33(1), 119-151. https://doi.org/10.1146/annurev.environ.33.022007.145142

Public Health England. (2013). Detection and enumeration of bacteria in swabs and other enviroenmental samples. Microbiology Services Food Water and Environmental Microbiology Standard Method About Public Health England. 22(2), 1-23.

Rajendran, K., Aslanzadeh, S., \& Taherzadeh, M. (2012). Household biogas digesters - a review. Energies, 5(12), 2911-2942. https://doi.org/10.3390/en5082911

Semple, S., Apsley, A., Wushishi, A., \& Smith, J. (2014). Commentary: Switching to biogas What effect could it have on indoor air quality and human health? Biomass and Bioenergy, 70, 125-129. https://doi.org/10.1016/j.biombioe.2014.01.054

Sobsey, M. D. (2006). Pathogens in animal wastes and the impacts of waste management practices on their survival, transport and fate. http://www.mwpshq.org/

Staal, S., Poole, J., Baltenweck, I., Mwacharo, J., Notenbaert, A., Randolph, T., Thorpe, W., Nzuma, J., \& Herrero, M. (2009). Targeting strategic investment in livestock development as a vehicle for rural livelihoods. Bill and Melinda Gates Foundation-ILRI Project on Livestock Knowledge Generation Project Report, October, 78. 
426 Tate KW, Atwill ER, Bartolome JW, N. G. (2006). Significant Escherichia coli attenuation by vegetative buffers on annual grasslands. J Environ Qual, 35, 795-805.

428

429

430

431

432

433

434

435

436

437

438

439

440

441
Tegegne A \& Gatachew Legese Feye. (2020). Working Paper 192 Study of Selected Livestock Innovations in Ethiopia (No. 192; ISSN 1864-6638).

Tumwesige, V., Davidson, G., Hutton, J., Orskov, B., \& Foundation, O. (2013). The potential of flexible balloon digesters to improve livelihoods in Uganda. A case study of Tiribogo. April.

United States Enviromental Protection Agency. (2013). July 2013. July.

Viau, E., \& Peccia, J. (2009). Evaluation of the enterococci indicator in biosolids using culturebased and quantitative PCR assays. Water Research, 43(19), 4878-4887. https://doi.org/10.1016/j.watres.2009.09.016

Watcharasukarn, M., Kaparaju, P., Steyer, J. P., Krogfelt, K. A., \& Angelidaki, I. (2009). Screening Escherichia coli, Enterococcus faecalis, and Clostridium perfringens as indicator organisms in evaluating pathogen-reducing capacity in biogas plants. Microbial Ecology, 58(2), 221-230. https://doi.org/10.1007/s00248-009-9497-9 